\title{
PENGARUH GAYA KEPEMIMPINAN DAN MOTIVASI TERHADAP KINERJA DENGAN MODAL PSIKOLOGIS SEBAGAI MODERATING
}

\author{
Muhammad Aldiansyah ${ }^{1}$, Hendra Lukito ${ }^{2}$ \\ 1) Program Studi Magister Manajemen Universitas Andalas \\ 2) Program Studi Magister Manajemen Universitas Andalas
}

\begin{abstract}
Abstrak : Suatu organisasi harus memiliki nilai lebih dalam hal sumber daya manusia agar dapat bersaing dengan organisasi lainnya. Organisasi dalam melaksanakan program kerja yang telah disusun pada dasarnya selalu bertujuan untuk mencapai tujuan organisasi. Salah satu caranya adalah dengan meningkatkan kinerja pegawai. Kinerja adalah hasil atau tingkat keberhasilan seseorang secara keseluruhan selama periode tertentu didalam melaksanakan tugas. Penelitian ini dilakukan bertujuan untuk mengetahui pengaruh gaya kepemimpinan dan motivasi terhadap kinerja dengan modal psikologis sebagai moderating pada pegawai Fakultas Ilmu Keolahragaan Universitas Negeri Padang. Variabel independen pada penelitian ini diantaranya gaya kepemimpinan dan motivasi, sedangkan kinerja pegawai dijadikan sebagai variabel dependen, dan modal psikologis sebagai variabel moderasi. Teknik pengambilan sampel dilakukan dengan sampling jenuh dimana menjadikan seluruh populasi sebagai sampel yang didapat sebanyak 66 pegawai yang ada pada Fakultas Ilmu Keolahragaan Universitas Negeri Padang. Dengan menggunakan instrumen berupa kuesioner yang dianalisa memakai analisis PLS-SEM, dimana hasil yang diperoleh yaitu gaya kepemimpinan dan motivasi berpengaruh signifikan dan positif terhadap kinerja pegawai. Modal psikologis dapat memoderasi gaya kepemimpinan dan motivasi terhadap kinerja pegawai. Disarankan kepada pimpinan Fakultas Ilmu Keolahragaan Universitas Negeri Padang perlu memberikan pelatihan pengembangan, update ilmu para pegawai, karena dalam pengisian kuesioner responden masih rendah nilai terampil dibandingkan standar prosedur yang ada dalam bekerja.
\end{abstract}

Kata Kunci : Gaya kepemimpinan, motivasi, modal psikologis, kinerja pegawai

Abstract : An organization must have more value in terms of human resources in order to compete with other organizations. Organizations in carrying out work programs that have been prepared basically always aim to achieve organizational goals. One way is to improve employee performance. Performance is the result or level of success of a person as a whole during a certain period in carrying out the task. Thisresearch was conducted to determine the effect of leadership model and motivation on performance with psychological capital as moderating for employees of the Faculty of Sports Science, Padang State University. The independent variables in this study include leadership model and motivation, while employee performance is used as the dependent variable, and psychological capital as a moderating variable. The sampling technique was carried out by saturated sampling which made the entire population as a sample obtained as many as 66 employees at the Faculty of Sports Science, Padang State University. By using an instrument in the form of a questionnaire which was analyzed using PLS-SEM analysis, where the results obtained were leadership model and motivation had a significant and positive effect on employee performance. Psychological capital can moderate leadership model and motivation on employee performance. It is recommended that the leadership of the Faculty of Sports Science, Padang State University, need to provide development training, update the knowledge of employees, because in filling out the questionnaire respondents the skill value is still low compared to standard procedures at work.

Keywords: Leadership model, motivation, psychological capital, employee performance 


\section{A. PENDAHULUAN}

Salah satu sumber daya organisasi yang paling memiliki peran penting dalam pencapaian tujuan suatu organisasi adalah sumber daya manusia. Karena pentingnya peran manusia, suatu organisasi harus memiliki nilai lebih dalam hal sumber daya manusia agar dapat bersaing dengan organisasi lainnya. Menurut Bangun (2015), suatu cara yang berkaitan dengan sumber daya manusia agar dapat menjadi sumber keunggulan bersaing adalah melalui peningkatan modal manusia (human capital) untuk dapat mengenal dan beradaptasi dengan lingkungan yang selalu berubah. Oleh karena itu sumber daya manusia harus dikelola dengan baik agar dapat bersaing.

Menurut Gibson (2013), kinerja pegawai dalam instansi dipengaruhi oleh banyak faktor antara lain kemampuan, keterampilan, motivasi, lingkungan kerja, kepuasan kerja, desain pekerjaan, gaya kepemimpinan, imbalan dan lain sebagainya. Sering terjadi kinerja pegawai menurun dikarenakan adanya ketidaknyamanan dalam bekerja, upah yang minim, kemampuan atau keahlian yang kurang mendukung dan juga ketidakpuasan dalam bekerja.

Kinerja pegawai dalam suatu organisasi dipengaruhi oleh gaya kepemimpinan. Menurut pendapat Bangun (2015), seseorang akan dapat mempengaruhi kinerja sebuah organisasi, tergantung pada bagaimana melakukan aktivitas kepemimpinan didalamnya. Kesalahan dalam menentukan gaya kepemimpinan akan berpengaruh terhadap penurunan kinerja, tingginya tingkat absensi, dan perputaran. Seorang pemimpin sangat perlu memperhatikan gaya kepemimpinan dalam proses mempengaruhi, mengarahkan kegiatan anggota kelompoknya serta mengordinasikan tujuan anggota dan tujuan organisasi agar keduanya dapat tercapai.

Gaya kepemimpinan yang baik adalah gaya kepemimpinan yang dapat memberikan motivasi kerja pada bawahannya. Hasibuan (2017) mengatakan seorang pemimpin harus melakukan berbagai keahlian, pengalaman, kepribadian setiap individu yang di pimpinnya. Gaya kepemimpinan yang efektif dibutuhkan dalam suatu perusahaan untuk dapat meningkatkan kinerja semua pegawai dalam mencapai tujuan yang telah di tetapkan perusahaan.

Faktor yang mempengaruhi kinerja pegawai selain gaya kepemimpinan adalah motivasi Pegawai. Pegawai dapat bekerja dengan baik jika diberikan motivasi tinggi. Motivasi tersebut hadir dari dalam diri pegawai itu sendiri maupun berasal dari lingkungan kerja ataupun berasal dari perusahaan. Motivasi dapat dipandang sebagai perubahan energi dalam diri seseorang yang ditandai dengan munculnya feeling, dan didahului dengan tanggapan terhadap adanya tujuan.

Motivasi adalah dorongan dasar yang menggerakkan seseorang atau keinginan untuk mencurahkan segala tenaga karena adanya suatu tujuan. Seperti yang dikemukakan oleh Mangkunegara (2013) motivasi merupakan kondisi atau energi yang menggerakkan diri pegawai yang terarah atau tertuju untuk mencapai tujuan organisasi perusahaan. Sikap mental pegawai yang positif terhadap situasi kerja itulah yang memperkuat motivasi kerjanya untuk mencapai kinerja yang maksismal. Tiga unsur yang merupakan kunci dari motivasi, yaitu upaya, tujuan organisasi, dan kebutuhan. Jadi motivasi dalam hal ini sebenarnya merupakan respons dari suatu aksi. Motivasi muncul dari dalam diri manusia karena dorongan oleh adanya unsur suatu tujuan. Tujuan ini menyangkut soal kebutuhan dapat dikatakan bahwa tidak akan ada suatu motivasi apabila tidak dirasakan adanya suatu kebutuhan.

Selain gaya kepemimpinan dan motivasi, hal yang perlu diperhatikan untuk meningkatkan kinerja pegawai adalah modal psikologis. Modal psikologis sendiri dapat diartikan sebagai modal sikap dan perilaku yang berperan besar dalam menentukan keberhasilan. Menurut Luthan, F; Youssef (2017), Modal psikologi adalah suatu perkembangan keadaan psikologis yang positif pada individu dengan karakteristik: (1) memiliki kepercayaan diri untuk memilih dan menyerahkan upaya yang diperlukan agar berhasil pada tugas-tugas yang menantang (self-efficacy); (2) membuat atribusi positif tentang keberhasilan dimasa kini dan mendatang (optimism); (3) tekun dalam mencapai tujuan dan, bila diperlukan mengalihkan cara untuk mencapai tujuan dalam rangka meraih keberhasilan (hope), dan; (4) ketika dilanda masalah dan kesulitan individu dapat bertahan dan bangkit kembali bahkan melampaui keadaan semula untuk mencapai keberhasilan (resiliency). 
Besarnya peranan pemimpin dalam perguruan tinggi terkait dengan kinerja SDM terutama dosen juga di kemukakan oleh Bachtiar (2013) mengemukakan bahwa banyak faktor penentu daya saing perguruan tinggi, namun yang paling menentukan adalah kepemimpinan yang cakap dan bertanggung jawab, baik pada tingkat universitas maupun pada tingkat fakultas dan program studi. Beberapa alasan pentingnya kepemimpinan perguruan tinggi adalah: (a) pimpinan yang berperan mempromosikan kompetensi institusi pada masayarakat, (b) pimpinan yang mendesain system recruitment staf akademik dan mahasiswa baru, (c) pimpinan yang memberikan motivasi dankewenangan pada ketua program studi untuk mengembangkan program studinya, (d) pimpinan yang memperbaiki atmosfir akademik dan kondisi kerja, dan (e) pimpinan yang menyatukan kepentingan dan minat yang beragam dalam proses belajar mengajar.

Dengan kata lain, dapat disimpulkan bahwa keempat komponen dari modal psikologis merupakan faktor penting yang dapat mempengaruhi perilaku positif dalam organisasi dan dunia kerja. Keberadaan pegawai menjadi salah satu poin penting dalam jalannya suatu organisasi birokrasi. Berbagai pekerjaan operasional maupun manajerial akan terasa lebih ringan dengan adanya dukungan dari para pegawaiyang mempunyai modal psikologi yang tinggi. Semakin tinggi modal psikologi pegawai akan berdampak semakin tinggi kinerja pegawai tersebut.

Perguruan tinggi merupakan lembaga utama dalam mencapai tujuan program pendidikan. Dalam kenyataannya keberhasilan pada tingkat ini justru yang menentukan keberhasilan pelaksanaan program pendidikan nasional.

Universitas Negeri Padang adalah salah satu Universitas yang terdepan yang ada di Kota Padang. Berdasarkan penilaian kinerja penelitian pada tahun 2019, UNP berada pada peringkat 26 dengan klasterisasi Mandiri yang sebelumnya berada pada klasterisasi Utama (sumbar.antaranews.com, 2020). Kinerja dari suatu perguruan tinggi ditentukan oleh kinerja pimpinan perguruan tinggi itu, untuk mencapai kinerja yang efektif dari suatu perguruan tinggi.

Namun kenyataan yang terjadi pada Universitas Negeri Padang khususnya di Fakultas Ilmu Keolahragaan Universitas Negeri Padang ditemukannya kinerja pegawai yang tidak optimal. Hasil pengamatan di Universitas Negeri Padang peneliti melihat beberapa masalah yaitu dimana peran pimpinan yang memimimpin pegawai untuk mencapai tujuan organisasi masih di rasa kurang terpenuhi, karena kurangnya perilaku seorang pemimpin yang menunjukkan upaya sungguh-sungguh dalam mengatasi berbagai hambatan tugas serta menyelesaikan masalah sebaik-baiknya yang di hadapai organisasi. dapat dilihat dari Kurangnya Empati kepemimpinan terhadap pegawai sehingga kurangnya hubungan yang baik antara pegawai dan pimpinan. Kurangnya cara pimpinan menjelaskan tujuan instansi kebawahan, dan menganggap dirinya selalu benar.

Hal tersebut tentu saja bisa menjadi hambatan para pegawai dalam bekerja untuk menghasilkan kinerja yang baik.Selanjutnya kondisi dimana seorang pegawai merasa kurang dalam pemberian reward oleh pihak organisasi terhadap hasil yang telah dicapai selama ini yang menyebabkan kinerja pegawai menjadi menurun dalam menyelesaikan pekerjaan yang diberikan dan kurangnya dorongan dari dalam diri pegawai dalam mengubah perilaku yang diinginkan oleh organisasi untuk mencapai tujuan, sehingga motivasi kerja diberikan oleh pegawai tidak optimal. Oleh karena itu, untuk mencapai kinerja yang diharapkan organisasi dibutuhkan motivasi pada pegawai. Dengan adanya motivasi dan penilaian kinerja, tujuan organisasi dapat tercapai serta tercapai pula tujuan pribadi. Pemberian motivasi kepada seseorang merupakan suatu mata rantai yang dimulai dari kebutuhan, menimbulkan keinginan, menimbulkan tindakan, dan menghasilkan keputusan. 


\section{B. METODE PENELITIAN}

Desain Penelitian. Penelitian ini termasuk penelitian asosiatif kausal yaitu penelitian yang bertujuan untuk mengetahui hubungan sebab akibat antara dua variable atau lebih yaitu variable independen terhadap variable dependen. Penelitian ini dilakukan dengan menggunakan metode kuantitatif, yaitu penelitian yang sifatnya dapat dihitung jumlahnya dengan menggunakan metode statistik (Sekaran., 2011). Dalam penelitian ini variable independen adalah gaya kepemimpinan. Sedangkan variabel moderasi adalah modal psikologis, dan variabel dependen adalah kinerja pegawai.

Populasi dan Sampel. Sampel merupakan sebagian dari jumlah dan karakteristik yang dimiliki oleh populasi atau sebagian populasi yang menjadi subyek penelitian yang dapat mewakili populasi penelitian (Arikunto, 2013). Teknik pengambilan sampel dalam penelitian ini adalah total sampling. Total sampling adalah teknik pengambilan sampel dimana jumlah sampel sama dengan populasi (Sugiyono, 2017). Alasan mengambil total sampling karena menurut Sugiyono (2017) jumlah populasi yang kurang dari 100 seluruh populasi dijadikan sampel penelitian semuanya. Sampel yang diambil dari penelitian ini adalah 66 pegawai Tenaga Kependidikan FakultasIlmu Keolahragaan Universitas Negeri Padang.

Definisi Variabel. Kinerja pegawai adalah suatu tingkat keberhasilan seorang pegawai dalam menjalankan pekerjaan yang diberikan kepadanya. Kinerja pegawai yang satu dengan yang lain tidaklah sama, karena setiap individu memiliki karakteristik dan kemampuan yang berbeda. Kinerja pegawai yang baik akan memudahkan perusahaan dalam pencapaian sasaran yang sudah ditetapkan. Mangkunegara (2016). Gaya kepemimpinan(Leadership Style) merupakan perilaku, strategi, sebagai hasil kombinasi dari falsafah, keterampilan, sifat, sikap yang digunakan seseorang pada saat orang tersebut mencoba mempengaruhi orang lain yang menjadi bawahannya (Rorimpandey, 2013). Motivasi adalah mempersoalkan bagaimana cara mengarahkan daya potensi bawahan, agar mau bekerja sama produktif berhasil mencapai dan mewujudkan tujuan yang telah ditentukan (Hasibuan, 2017). Modal psikologis mencakup pengalaman, pendidikan, keterampilan, pengetahuan dan ide-ide. Modal social menekankan hubungan, jaringan kontak, dan pertemanan. Sedangkan, modal psikologis yang positif menekankan pada kepercayaan, harapan, optimisme dan ketahanan (Luthans, 2015).

\section{HASIL DAN PEMBAHASAN}

Outer loading Pada aplikasi PLS-SEM atau CB-SEM dilakukan penilaian model pada pengukuran reflektif meliputi beberapa aspek dari konstruk model : realibilitas, konstruk, validitas konvergen, validitas diskriminan dan indicator loading ( Hair et al., 2018). Pada PLSSEM , penilaian outer loading diperiksa terlebih dahulu pembebanan indikatornya hingga memperlihatkan bahwa pada konstruksi menjelaskan lebih dari 50 persen varian indikator. Pada indicator ditunjukan keunggulan item yang bisa diterima secara jelas, sebesar minimal 0,50. (Hair et al., 2018). Hasil dari pengolahan data dapat dilihat pada table berikut ini:

Tabel 1.1

\begin{tabular}{|c|c|c|c|}
\hline Item & Outer Loading & Item & Outer Loading \\
\hline GK4 & 0.649 & M1 & 0.581 \\
\hline GK5 & 0.855 & M2 & 0.742 \\
\hline GK6 & 0.827 & M3 & 0.903 \\
\hline GK7 & 0.866 & M4 & 0.925 \\
\hline GK8 & 0.875 & M7 & 0.511 \\
\hline GK9 & 0.927 & M9 & 0.694 \\
\hline GK10 & 0.763 & M10 & 0.763 \\
\hline
\end{tabular}




\begin{tabular}{|c|c|c|c|}
\hline Item & Outer Loading & Item & Outer Loading \\
\hline KP1 & 0.737 & MP2 & 0.899 \\
\hline KP2 & 0.954 & MP3 & 0.891 \\
\hline KP3 & 0.911 & MP4 & 0.859 \\
\hline KP4 & 0.956 & MP5 & 0.551 \\
\hline KP5 & 0.928 & MP6 & 0.859 \\
\hline KP6 & 0.964 & MP7 & 0.950 \\
\hline KP7 & 0.888 & MP8 & 0.768 \\
\hline KP8 & 0.858 & MP9 & 0.909 \\
\hline & & MP10 & 0.897 \\
\hline
\end{tabular}

Sumber: Hasil Pengolahan Data Primer, 2021

Convergent validity. Pengujian convergent validity adalah metrik keseluruhan dari model pengukuran reflektif yang mengukur sejauh mana indikator konstruk konvergen, sehingga menjelaskan varian item. Hal ini sering di kenal dengan komunalitas, penilaiannya dilakukan dengan mengevaluasi rata rata pada varian ektraksi (AVE) pada semua indikator yang berhubungan secara konstruk tertentu. AVE merupakan rata-rata (mean) dari beban kuadrat dari semua indikator yang terkait dengan konstruksi tertentu. Aturan praktis untuk nilai AVE yang bisa diterima yaitu 0,50 atau lebih tinggi. Angka pada level ini atau lebih tinggi menunjukkan bahwa rata-rata konstruksi menjelaskan 50 persen atau lebih varians dari indikatornya (Hair et al., 2018).

Discriminant validity. Validitas diskriminan untuk menilai seberapa unik indikator-indikator suatu konstruk merepresentasikan konstruk itu sendiri (varian bersama dalam konstruk itu) versus seberapa banyak konstruk itu berkorelasi dengan semua konstruk lain dalam model (varian bersama antar konstruk). Uji validitas diskriminan dilakukan untuk semua pasangan konstruksi reflektif dalam model. Menggunakan konsep AVE yang dibahas di atas, validitas diskriminan hadir ketika varian bersama dalam sebuah konstruksi (AVE) selalu melebihi varian bersama dengan konstruksi lainnya (Hair et al., 2018).

Construct reliability. Penentukan keandalan konsistensi internal setiap konstruk. Meskipun cronbach's alpha adalah metode yang banyak digunakan untuk menilai keandalan, pada metode ini tidak membobotkan indikator individu dalam perhitungan. Keandalan komposit (composite reliability) mengatasi batasan ini karena bobot indikator individu berdasarkan bebannya dan oleh karena itu merupakan pendekatan keandalan yang disukai. Keandalan komposit (composite reliability) lebih disukai tetapi alpha cronbach dapat diterima. Keandalan minimum yang direkomendasikan adalah 0,70 , kecuali untuk studi eksplorasi, di mana 0,60 dianggap sebagai minimum (Hair et al., 2018)

$\boldsymbol{R}$-Square (R2). Pengujian measurement models koefisien determinasi merupakan ukuran insample daya prediksi, rentang nilai R2 dari 0 sampai 1 , dimana 0 menunjukkan tidak ada hubungan dan 1 menunjukkan hubungan yang sempurna. Semakin tinggi nilai R2 semakin besar daya penjelas dari model struktural PLS, dan Oleh karena itu semakin baik prediksi konstruk endogen (Hair et al., 2018). R-Square merupakan uji goodness-fit model.

Uji Hipotesis. pengujian hipotesis menggunakan bootstrap melibatkan penilaian pada ukuran dan signifikansi terhadap koefisien jalur, bootstrap tersebut merupakan prosedur yang dilakukan untuk mendapatkan signifikansi. Sama dengan halnya penilaian bobot pada indikator formatif proses bootstrap menggunakan kesalahan standar untuk bisa menghitung nilai $t$ dan $p$ untuk koefisien jalur. Bisa dikoreksi dan percepatan interval kepercayaan juga diperiksa, dan koefisien jalur signifikan pada tingkat 0,05 (Hair et al., 2018). Untuk melihat signifikansi pengaruh gaya kepemimpinan, motivasi dan modal psikologis terhadap kinerja pegawai adalah dengan melihat nilai koefisien parameter dan nilai signifikansi t-statistic dan P-value. Tingkat 
signifikansi dalam pengujian hipotesis ditujukan oleh nilai koefisien path atau inner model. Hasil dari dari koefisien path atau inner model dapat dilihat pada Tabel 1.2

Tabel 1.2

Path Coefficients

\begin{tabular}{|l|c|c|c|}
\hline & $\begin{array}{c}\text { Original } \\
\text { Sample (O) }\end{array}$ & $\begin{array}{c}\text { T Statistics } \\
(\mid \mathbf{O} / \text { STDEV })\end{array}$ & P Values \\
\hline $\begin{array}{l}\text { Gaya Kepemimpinan -> } \\
\text { Kinerja pegawai }\end{array}$ & 0.607 & 5.897 & 0.000 \\
\hline $\begin{array}{l}\text { Modal Psikologis -> } \\
\text { Kinerja pegawai }\end{array}$ & 0.927 & 9.304 & 0.000 \\
\hline $\begin{array}{l}\text { Motivasi -> } \\
\text { Kinerja pegawai }\end{array}$ & 0.281 & 3.385 & 0.001 \\
\hline $\begin{array}{l}\text { Gaya Kepemimpinan -> } \\
\text { Modal psikologis -> } \\
\text { Kinerja pegawai }\end{array}$ & 0.649 & 5.400 & 0.000 \\
\hline $\begin{array}{l}\text { Motivasi -> } \\
\text { Modal psikologis -> } \\
\text { Kinerja pegawai }\end{array}$ & 0.621 & 9.627 & 0.000 \\
\hline
\end{tabular}

Sumber: Hasil Pengolahan Data Primer, 2021

Pengujian koefisien path atau inner model dilakukan untuk menguji pengaruh hubungan langsung antara gaya kepemimpinan, motivasi, dan modal psikologis terhadap kinerja pegawai. Suatu variabel dinyatakan berpengaruh signifikan dengan cara melihat nilai p-values dan TStatistik, apabila nilai p-values yang diperoleh lebih kecil dari 0,05 dan T-statistik lebih besar dari 1,98 maka suatu variabel dinyatakan berpengaruh signifikan begitu juga sebaliknya. Sedangkan untuk melihat arah (slot) dari variabel independent terhadap variabel dependent dapat dilihat dari nilai koefisien yang diperoleh.

Hasil pengujian koefisien path atau inner model pada penelitian ini dapat dilihat pada Tabel 1.2, dengan hasil dan keterangan sesuai dengan hipotesis yang diajukan sebagai berikut:

Gaya kepemimpinan memiliki nilai koefisien 0,607 maka gaya kepemimpinan berpengaruh positif dan signifikan terhadap kinerja pegawai Fakultas Ilmu Keolahragaan Universitas Negeri Padang. Setiap peningkatan gaya kepemimpinan sebesar 1 satuan maka kinerja pegawai akan meningkat sebesar 0,607 satuan. Semakin baik gaya kepemimpinan di dalam Fakultas Ilmu Keolahragaan Universitas Negeri Padang, maka akan meningkatkan kinerja pegawai. Pada penelitian ini nilai t statistik sebesar 5.897 lebih besar dari t tabel (1.998), nilai $\mathrm{P}$ value sebesar $0.000<0,05$ maka Tolak H0 Terima H1 artinya gaya kepemimpinan berpengaruh positif signifikan terhadap kinerja pegawai di Fakultas Ilmu Keolahragaan Universitas Negeri Padang.

Motivasi memiliki nilai koefisien 0.281 maka motivasi berpengaruh positif dan signifikan terhadap kinerja pegawai Fakultas Ilmu Keolahragaan Universitas Negeri Padang. Setiap peningkatan motivasi sebesar 1 satuan maka kinerja pegawai akan meningkat sebesar 0.281 satuan. Semakin baik motivasi di dalam Fakultas Ilmu Keolahragaan Universitas Negeri Padang, maka akan meningkatkan kinerja pegawai. Pada penelitian ini nilai t statistik sebesar 3.385 lebih besar dari t tabel (1.998), nilai P value sebesar $0.001<0,05$ maka Tolak H0 Terima H2 artinya motivasi berpengaruh positif signifikan terhadap kinerja pegawai di Fakultas Ilmu Keolahragaan Universitas Negeri Padang.

Gaya kepemimpinan memiliki nilai koefisien 0.649 maka gaya kepemimpinan berpengaruh positif dan signifikan terhadap kinerja pegawai Fakultas Ilmu Keolahragaan Universitas Negeri Padang yang dimoderasi oleh modal psikologis. Setiap peningkatan gaya kepemimpinan yang dimoderasi oleh modal psikologi sebesar 1 satuan maka kinerja pegawai akan meningkat sebesar 0.649 satuan. Pada penelitian ini nilai t statistik sebesar 5.400 lebih besar dari t tabel 
(1.998), nilai $\mathrm{P}$ value sebesar $0.000<0,05$ maka Tolak H0 Terima H3 artinya gaya kepemimpinan berpengaruh terhadap kinerja pegawai Fakultas Ilmu Keolahragaan Universitas Negeri Padang yang dimoderasi oleh modal psikologis.

Motivasi memiliki nilai koefisien 0.621 maka motivasi berpengaruh positif dan signifikan terhadap kinerja pegawai Fakultas Ilmu Keolahragaan Universitas Negeri Padang yang dimoderasi oleh modal psikologis. Setiap peningkatan motivasi yang dimoderasi oleh modal psikologi sebesar 1 satuan maka kinerja pegawai akan meningkat sebesar 0.621 satuan. Pada penelitian ini nilai t statistik sebesar 9.627 lebih besar dari t tabel (1.998), nilai $\mathrm{P}$ value sebesar $0.000<0,05$ maka Tolak H0 Terima H4 artinya motivasi berpengaruh terhadap kinerja pegawai Fakultas Ilmu Keolahragaan Universitas Negeri Padang yang dimoderasi oleh modal psikologis. Gaya Kepemimpinan Berpengaruh Positif dan Signifikan Terhadap Kinerja Pegawai. Berdasarkan hasil hipotesis diatas, menunjukkan bahwa terdapat hubungan positif dan signifikan antara gaya kepemimpinan terhadap kinerja pegawai. Artinya, semakin besar seseorang memiliki gaya kepemimpinan, maka akan semakin bagus juga kinerja pegawai.

Gaya kepemimpinan merupakan suatu cara yang digunakan pemimpin dalam berinteraksi dengan bawahannya. Gaya kepemimpinan adalah pola tingkah laku (kata-kata dan tindakantindakan) dari seorang pemimpin yang dirasakan oleh orang lain. Seorang pemimpin harus menerapkan gaya kepemimpinan untuk mengelola bawahannya, karena seorang pemimpin akan sangat mempengaruhi keberhasilan organisasi dalam mencapai tujuannya. Semakin tegas gaya kepemimpinan seorang pemimpin maka akan meningkatkan kinerja pegawai. Kepemimpinan sangat dibutuhkan untuk memberikan pengarahan terhadap usaha-usaha semua pekerja dalam mencapai tujuan-tujuan organisasi. Tanpa pemimpin atau bimbingan, hubungan antara tujuan organisasi mungkin menjadi renggang. Oleh karena itu, kepemimpinan sangat diperlukan bila suatu organisasi ingin sukses.

Gaya kepemimpinan terhadap kinerja, dapat disimpulkan bahwa gaya kepemimpinan mempunyai pengaruh yang signifikan terhadap kinerja pegawai. Gaya kepemimpinan yang tepat akan menimbulkan motivasi kerja agar pegawai bekerja sesuai dengan harapan organisasi. Gaya kepemimpinan pimpinan Fakultas Ilmu Keolahragaan Universitas Negeri Padang, demokratis dan menerima saran dari pegawai pegawai yang bersifat membangun. Gaya kepemimpinan yang cakap dan demokratis membantu dalam peningkatan kinerja pegawai Fakultas Ilmu Keolahragaan Universitas Negeri Padang.

Penelitian ini sejalan dengan penelitian Kamal \& Abdillah (2019) didapatkan hasil bahwa adamya hubungan yang positif atau searah antara gaya kepemimpinan terhadap kinerja pegawai pada PT Pandu Siwi Sentosa. Penelitian ini juga sejalan dengan penelitian Endah Susetyo, (2017) Gaya Kepemimpinan memiliki pengaruh yang signifikan terhadap kinerja pegawai dalam penelitian ini terbukti. Penelitian Shella (2018) terdapat pengaruh positif dan signifikan gaya kepemimpinan terhadap kinerja pegawai di PT Pos Indonesia (Persero) Kabupaten Kebumen.

Motivasi Berpengaruh Positif dan Signifikan Terhadap Kinerja Pegawai. Berdasarkan hasil hipotesis diatas, menunjukkan bahwa terdapat hubungan positif dan signifikan antara motivasi terhadap kinerja pegawai. Semakin tinggi motivasi kerja pegawai Fakultas Ilmu Keolahragaan Universitas Negeri Padang maka akan meningkatkan kinerja pegawai bekerja. Motivasi kerja yang diberikan Fakultas Ilmu Keolahragaan Universitas Negeri Padang kepada pegawai berupa penghargaan sangat membantu terhadap peningkatan kinerja pegawai kerja.

Motivasi merupakan pemberian dorongan dorongan individu untuk bertindak yang menyebabkan orang tersebut berperilaku dengan cara tertentu yang mengarah pada tujuan. Pemberian motivasi merupakan salah satu tujuan agar pegawai yang diberi motivasi dapat bekerja sesuai dengan acuan kerja dan taggung jawab yang diberikan sehingga tujuan perusahaan dapat tercapai dengan baik. Selain itu, juga terkandung unsur-unsur upaya, yaitu upaya yang berkualitas dan diarahkan serta konsisten dengan tujuan-tujuan organisasi yang ingin dicapai.

Motivasi seseorang menunjukkan arah tertentu kepadanya dalam mengambil langkah-langkah yang perlu untuk memastikannya sampai pada tujuan. Sedangkan bermotivasi berarti 
menginginkan sesuatu berdasarkan keinginan sendiri atau terdorong oleh apa saja yang ada untuk mencapai keberhasilan. Faktor internal antara lain prestasi, pengakuan/penghargaan, tanggung jawab, memperoleh kemajuan dan perkembangan dalam bekerja. Faktor eksternal antara lain gaji/upah, hubungan antara pekerja, supervisi teknis, kondisi kerja, kebijaksanaan kantor, dan proses kerja di kantor. Pemberian motivasi dan penegakkan disiplin oleh atasan berarti telah memberikan kesempatan terhadap pegawai yang menjadi bawahannya, sehingga pegawai bisa dan mampu mengembangkan kemampuannya. Motivasi yang diberikan ini juga merupakan dorongan semaksimal mungkin pegawai untuk bekerja.

Hasil penelitian ini sejalan dengan penelitian yang dilakukan oleh Mahardika et al (2020) Motivasi berpengaruh signifikan terhadap kinerja pegawai pada PT. AXA Financial Indonesia, ditunjukkan dengan nilai signifikansi t sebesar 0,000 lebih kecil dari $\mathrm{D}=0,05(0,000<0,05)$ dengan koefisien regresi sebesar 0,514. Penelitian yang dilakukan Endah Susetyo, (2017) didapatkan hasil bahwa Motivasi memiliki pengaruh yang signifikan terhadap kinerja pegawai dalam penelitian ini tidak terbukti.

Pengaruh Gaya Kepemimpinan Terhadap Kinerja Pegawai yang Dimoderasi Oleh Modal Psikologis. Berdasarkan hasil hipotesis diatas, menunjukkan bahwa terdapat hubungan positif dan signifikan antara gaya kepemimpinan terhadap kinerja pegawai yang dimoderasi oleh modal psikologis. Artinya gaya kepemimpinan memiliki pengaruh terhadap kinerja pegawai Fakultas Ilmu Keolahragaan Universitas Negeri Padang dengan adanya modal psikologi akan menambah kinerja pegawai lebih baik, semakin tinggi gaya kepemimpinan yang ditampilkan maka akan dapat meningkatkan modal psikologis individu, yang terdiri atas efikasi diri, optimism, harapan, dan ketahanan dalam menghadapi hambatan maupun permasalahan yang dihadapinya pegawai Fakultas Ilmu Keolahragaan Universitas Negeri Padang.

Penelitian Riaz dan Haider (2016) menyebutkan bahwa gaya kepemimpinan memiliki pengaruh yang lebih baik terhadap kinerja, inovasi serta modal psikologis sendiri dapat diartikan sebagai modal sikap dan perilaku yang berperan besar dalam menentukan keberhasilan. Penelitian yang dilakukan oleh Harun, Luthfi \& Ahmed (2019) yang melibatkan 327 pegawai di sector perhotelan di Turki menemukan bahwa gaya kepemimpinan memiliki pengaruh positif pada modal psikologis pegawai.

Pengaruh Motivasi Terhadap kinerja Pegawai yang Dimoderasi Oleh Modal Psikologis. Berdasarkan hasil hipotesis diatas, menunjukkan bahwa terdapat hubungan positif dan signifikan antara motivasi terhadap kinerja pegawai yang dimoderasi oleh modal psikologis. Artinya, pegawai dengan pelaksana yang memiliki motivasi tinggi, dalam pekerjaan akan selalu mencoba melakukan yang terbaik serta bersedia meluangkan waktu dan upaya ekstra untuk melakukan pekerjaannya sehingga akan meningkatkan kinerjanya pegawai, sementara modal psikologis mendapatkan perhatian untuk dapat meningkatkan performa/kinerja pegawai Fakultas Ilmu Keolahragaan Universitas Negeri Padang, dengan meningkatnya Kinerja pegawai, memberikan jalan bagi pegawai untuk mencapai tujuan karir mereka, secara realistis, optimis, dan memberi keyakinan untuk melakukan perubahan positif di tempat kerja, lingkungan dan bangkit kembali jika mengalami kegagalan. Motivasi merupakan faktor penting dalam mencapai kinerja tinggi. Kunci dalam prinsip motivasi bahwa kinerja merupakan fungsi dari kemampuan (ability) dan motivasi. Kinerja pegawai erat kaitannya dengan hasil pekerjaan seseorang dalam suatu organisasi, hasil pekerjaan tersebut dapat menyangkut kualitas, kuantitas, dan ketepatan waktu.

Hasil penelitian yang dilakukan oleh Iktiagung dan Pratiwi (2016) didapatkan hasil bahwa modal psikologi berpengaruh signifikan terhadap kinerja pegawai. Hipotesis pada penelitian ini diterima, ini memberikan informasi bahwa modal psikologi yang dimiliki setiap PNS di lingkungan Setda Kab. Blora belum dapat meningkatkan kinerja pegawai. Hasil penelitian yang dilakukan oleh Fiandri (2019) didapatkan hasil bahwa ecara langsung modal psikologis, motivasi, dan inovasi berpengaruh signifikan dan positif terhadap kinerja usaha kecil sektor kuliner. Selain itu, secara tidak langsung modal psikologis dan motivasi berpengaruh signifikan dan positif terhadap kinerja melalui inovasi. 


\section{PENUTUP}

Kesimpulan. Gaya kepemimpinan berpengaruh signifikan dan bernilai positif terhadap kinerja pegawai di Fakultas Ilmu Keolahragaan Universitas Negeri Padang. Motivasi berpengaruh positif signifikan terhadap kinerja pegawai secara parsial di Fakultas Ilmu Keolahragaan Universitas Negeri Padang. Gaya kepemimpinan berpengaruh terhadap kinerja pegawai Fakultas Ilmu Keolahragaan Universitas Negeri Padang yang dimoderasi oleh modal psikologis. Motivasi berpengaruh terhadap kinerja pegawai Fakultas Ilmu Keolahragaan Universitas Negeri Padang yang dimoderasi oleh modal psikologis.

\section{E. DAFTAR PUSTAKA}

Abdillah, W. dan J. H. (2014). Partial Least Square (PLS). Yogyakarta: Andi.

Adlina, F., Wiroko, E. P., \& Hayuwardhani, F. D. W. T. (2018). Modal Psikologis dan Persepsi Dukungan Organisasi terhadap Kesiapan Individu untuk Berubah pada Pegawai PPPKPKKP. Psympathic : Jurnal Ilmiah Psikologi, 5(2), 211-220.

Bachtiar, D. I. (2013). Analisan Faktor-faktor yang Mempengaruhi Kepuasan Mahasiswa dalam Memilih Politeknik Sawunggalih Aji Purworejo. Dinamika Sosial Ekonomi, 7(1).

Bangun, W. (2015). Sumber Daya Manusia. Jakarta: Erlangga.

Carr, A. (2014). Positive Psychology: The Science of Happiness and Human Strengths. Hove \& NewYork : Brunner - Routledge Taylor: Francis Group.

Colquitt, J., LePine, J., \& Wesson, M. Manajemen kinerja, Manajemen Kinerja/Wibowo -Jakarta: Rajawali Pers, $\S(2011)$.

Endah Susetyo, I. (2017). Pengaruh Gaya Kepemimpinan, Motivasi Dan Disiplin Kerjaterhadap Kinerja Pegawai Dengan Pemahaman Etika Kerja Islami. jurnal Upajiwa Dewantara, $1(2), 40$.

Fahmi, I. (2014). Perilaku Organisasi: Teori, Aplikasi, dan Kasus. Cetakan Kedua (CV. Alfabe). Bandung.

Fleeson, W., Jayawickreme, E., Jones, A. B. A. P., Brown, N. A., Serfass, D. G., Sherman, R. A., ... Matyjek-, M. (2017). Analisis Pengukuran Kinerja Sumber Daya Manusia Menggunakan Metode Human Resources Scorecard (Hrsc) Dan Analytical Hierarchy Process (Ahp) (Studi Kasus Di PT. Refi Chemical Industry, Sleman). Journal of Personality and Social Psychology.

Ghozali \& Latan. (2015). Partial Least Square SEM (PLS - SEM). Partial Least Square.

Ghozali, I. (2016). Aplikasi Analisis Multivariate dengan Program IBM SPSS 23.

Gibson. (2013). Penilaian Kinerja. Jakarta: Penerbit Erlangga.

Hadromi, F. Al. (2017). Analisis Pengaruh Gaya Kepemimpinan Kepala Sekolah Terhadap Motivasi, Kedisiplinan Dan Kinerja Guru Di Sd Islam Lumajang. Jurnal Bisnis Dan MAnajemen, 11(1), 109-123.

Hartono, J. (2011). Metodologi Penelitian Bisnis: Salah Kaprah dan Pengalaman-pengalaman. 
Yogyakarta: BPFE.

Hasibuan. (2016). Organisasi dan Motivasi. In Jakarta: PT Bumi Aksara.

Heidjrachman, D. (2010). Manajemen Personalia (edisi 4 ). Yogyakarta: BPFE.

Iktiagung dan Pratiwi. (2016). Pengaruh Karakteristik Pekerjaan dan Modal Psikologi terhadap Kepuasan Kerja untuk Meningkatkan Kinerja PNS di Sekretariat Daerah Kabupaten Blora. Journal \& Proceeding feb Unsoed, 6(1), 49-64.

Kamal, F., \& Abdillah, E. Z. (2019). Pengaruh Gaya Kepemimpinan Terhadap Kinerja Pegawai (Studi Kasus: Pt Pandu Siwi Sentosa Jakarta). Optimal: Jurnal Ekonomi dan Kewirausahaan, 12(2), 103-122.

Kaswan. (2017). Psikologi Industri dan Organisasi. Bandung: Alfabeta.

Krisanti, Y. V., Rostiana, R., \& Lie, D. (2017). Peran Dukungan Organisasi Dan Modal Psikologis Terhadap Psychological Ownership. Jurnal Muara Ilmu Sosial, Humaniora, dan Seni, 1(2), 418.

Luthan, F; Youssef, C. M. . \& A. (2017). Psychological Capital: Developing the Human Competitive Edge. NY: Oxford: University Press.

Luthans, F. (2015). Perilaku Organisasi, Edisi Sepuluh. Yogyakarta: Penerbit Andi.

Mahardika, R., Hamid, D., \& Ruhana, I. (2020). Pengaruh Motivasi Kerja Terhadap Kinerja Pegawai PT. Axa Financial Indonesia Sales Office Malang. Jurnal Mitra Manajemen, 4(6), $1-10$.

Malayu S.P Hasibuan. (2017). Manajemen Sumber Daya Manusia. Jakarta: PT.Bumi Aksara.

Mangkunegara, A. A. A. P. (2016). Manajemen Sumber Daya Manusia Perusahaan. In Remaja Rosdakarya.

Notoatmojo, S. (2010). Pengembangan Sumber daya manusia. In Jurnal LPPM Bidang EkoSosBudKum (Vol. 2, hal. 124).

Ovita Susiana, R. dkk. (2020). Pengaruh Gaya Kepemimpinan Dan Budaya Organisasi Terhadap Kinerja Pegawai Dengan Penerapan Good Corporate Goverment (GCG) Sebagai Variabel Intervening (Studi pada PT Taspen (PERSERO) Kantor Pusat Jakarta). CommerceJurnal Ilmiah Politeknik Piksi Input Serang, 7(3), 1-6.

Philip Kotler dan Gery Amstrong. (2012). Aktiviti Promosi.

Prawirosentono, S. (2008). Kebijakan Kinerja Pegawai. Journal of Experimental Psychology: General.

Purwanto, A., Asbari, M., \& Hari Hadi, A. (2020). Pengaruh Gaya Kepemimpinan Tansformational, Authentic, Authoritarian, Transactional terhadap Kinerja Guru Pesantren di Tangerang. Dirasah: Jurnal Studi Ilmu dan Manajemen Pendidikan Islam, $3(1), 85-110$. 
Rivai Veitzhal. (2013). Manajemen Sumber Daya Manusia.

Robert, H. (2016). Path-goal Theory of Leadership:Lessons, Legacy, Anda Reformulated Theory. "Leadership Quarterly, 7(3).

Rorimpandey, L. (2013). Gaya Kepemimpinan Transformasional, Transaksional, Situasional, Pelayanan Dan Autentik Terhadap Kinerja Pegawai Kelurahan Di Kecamatan Bunaken Kota Manado. Jurnal Riset Ekonomi, Manajemen, Bisnis dan Akuntansi.

Schaufeli. (2016). Same Same" But Different? Can Work Engagement be Discriminated From Job Involvement And Organizational commitment European Psychologist.

Sekaran, U. (2011). Research Methods for Business (Metodologi Penelitian Untuk Bisnis). Metode Penelitian.

Sekaran, Uma, \& Bougie, R. (2017). Research Method for Business Textbook: A Skill Building Approach. John Wiley \& Sons Ltd.

Shella, P. \& W. (2018). Pengaruh Gaya Kepemimpinan, Budaya Organisasi, Dan Lingkungan Kerja Terhadap Kinerja Pegawai Dengan Kepuasan Kerja Sebagai Mediator. Economic Education Analysis Journal, 7(2), 543-552.

Silen, A. P. (2016). Pengaruh Modal Psikologi Dan Keterlibatan Pegawai Terhadap Kinerja Pegawai Dengan Kepuasan Kerja Sebagai Variabel Mediasi (Studi Pegawai Politeknik Ilmu Pelayaran Semarang). Jurnal Manajemen Teori dan Terapan| Journal of Theory and Applied Management, 9(3), 161-175.

Simamora, H. (2018). Studi Kasus Manajemen Sumber Daya Manusia: Tinjanan Aplikasi Sistem Informasi. Seribu Bintang.

Stephen P. Robins, M. C. (2012). Management. Prentice Hall.

Sugiono. (2016). Metode Penelitan Kuantitatif, kualitatif dan R\&D. Bandung: Alfabeta.

Suprihati. (2014). Analisis Faktor- Faktor Yang Mempengaruhi Kinerja Pegawai Perusahaan Sari Jati di Sragen. paradigma.

Tampubolon. (2015). Perguruan Tinggi Bermutu. Jakarta: Gramedia Pustaka Utama.

Veithzal, R. (2014). Kepemimpinan dan perilaku organisasi. Jakarta: PT. Raja Grafindo.

Winardi. (2015). Motivasi Pemotivasian. Jakarta: PT. Raja Grafindo Persada.

Yuniarti, A. (2016). Pengaruh modal psikologis dan persepsi gaya kepemimpinan transformasional terhadap workplace well being. Tazkiya Journal of Psychology, 4(2), $126-147$.

Zaman, N. (2017). Pengaruh Modal Psikologi dan Organizational Citizenship Behavior Terhadap Kinerja Dimediasi oleh Kepuasan Kerja. Jurnal Bisnis dan Ekonomi, 24(1), 50-61.

Zaputri, A. R., Rahardjo, K., Utami, H. N., \& Administrasi, F. I. (2013). pengaruh insentif material dan non material terhadap kepuasan kerja dan kinerja pegawai (studi pada pegawai produksi cetak pt. temprina media grafika di surabaya)". Jurnal Administrasi Bisnis. 